\title{
First report of the intracellular fish parasite Sphaerothecum destruens associated with the invasive topmouth gudgeon (Pseudorasbora parva) in France
}

\author{
Amélie Charrier ${ }^{1, *}$, Margaux Peudpiece ${ }^{1,2}$, Mélanie Lesne ${ }^{1}$ and Patrick Daniel ${ }^{1}$ \\ ${ }^{1}$ Laboratoires des Pyrénées et des Landes, 1 Rue Marcel David, BP 219, 40004 Mont de Marsan, France \\ ${ }^{2}$ IUT des Pays de l'Adour - Département Génie Biologique, Rue du Ruisseau, BP 201, 40004 Mont de Marsan, France
}

\begin{abstract}
Sphaerothecum destruens has emerged as a serious parasite of fish. Its life cycle, as well as its association with Asian cyprinids, allows it to infect a wide range of hosts. The topmouth gudgeon (Pseudorasbora parva), an invasive species that has rapidly colonized Europe, has been shown to be a healthy carrier of the parasite. However, in France, the presence of $S$. destruens and its possible association with $P$. parva have not yet been demonstrated. Here, we screened topmouth gudgeon DNA for $S$. destruens using PCR amplification of an 18S rRNA gene fragment of the parasite. Sequencing and phylogenetic analysis confirmed the presence of $S$. destruens in the invasive fish species. Our results suggest that $P$. parva can be a potent vector of the parasite, and has the potential to become a major ecological and economic threat to the French fish population.
\end{abstract}

Keywords: Sphaerothecum destruens / Pseudorasbora parva / invasive species / topmouth gudgeon / France

Résumé - Première mise en évidence de l'association de Sphaerothecum destruens avec Pseudorasbora parva en France. Sphaerothecum destruens est apparu dans la littérature scientifique comme un redoutable parasite émergent de poissons. Son cycle de vie, ainsi que son association à un cyprinidé d'origine asiatique, lui permettent d'infecter un large spectre d'hôtes. En effet, le goujon asiatique (Pseudorasbora parva) s'est révélé être porteur sain de ce parasite dans plusieurs études et représente une des espèces invasives ayant colonisé le plus rapidement l'Europe et notamment la France. Bien que le statut de porteur sain ait été donné au goujon asiatique, à notre connaissance, aucune étude n'a été menée en France afin de démontrer cette association. Par conséquent, l'objectif de cette étude a été d'évaluer la présence de $S$. destruens dans ce pays et la possibilité de considérer Pseudorasbora parva comme un vecteur de la maladie. Ceci a été confirmé par amplification PCR d'un fragment du gène ARNr 18S du parasite, réalisée sur un extrait d'ADN obtenu à partir de plusieurs goujons. Un séquençage et une analyse phylogénétique ont par la suite confirmé qu'il s'agissait bien de $S$. destruens. Ces résultats permettent donc d'affirmer que l'espèce invasive $P$. parva pourrait présenter une grande menace aussi bien écologique qu'économique sur le territoire français.

Mots-clés : Sphaerothecum destruens / Pseudorasbora parva / espèces invasives / goujon asiatique / France

Sphaerothecum destruens, a unicellular eukaryotic parasite of fish, is a pathogen on the fungal-animal boundary that has been implicated in severe infectious disease in salmonids in North America (Ercan et al., 2015). This parasite was first described in Chinook salmon (Oncorhynchus tshawytscha) held in seawater net pens in the state of Washington, USA, causing systemic disease leading to high mortality (over 80\%)

\footnotetext{
* Corresponding author: a.charrier@labopl.com
}

in 3-year-old fish broodstock (Harrell et al., 1986). It was originally called the Chinook salmon rosette agent because of its occurrence in clusters in fish tissues (Harrell et al., 1986). This rosette agent was later identified as the cause of chronic mortality in Atlantic salmon (Salmo salar) reared in freshwater at a private farm in northern California (USA) (Hedrick et al., 1989). Later, similar organisms have also been found in winter-run Chinook salmon reared in captivity at the Bodega Marine Laboratory in California (Arkush et al., 1998). 
These three American isolates have been deposited in the American Type Culture Collection (ATCC), designated as RA-1 (Chinook salmon in Washington), RA-2 (Atlantic salmon in California) and RA-3 (winter-run Chinook salmon in California) under accession numbers ATCC 50643, ATCC 50644, and ATCC 50615, respectively (Arkush et al., 2003). Experiments conducted on the parasite's life cycle and on phylogenetic data led to the classification of the rosette agent as a new genus, designated as $S$. destruens (Arkush et al., 2003).

The spore stage of $S$. destruens reproduces asexually within the host cells. This intracellular multiplication occurs in various organs, accumulating until the host cells burst, leading to cell death and eventually chronic fish mortality. Infected fish release the spores into the water through urine, bile and reproductive fluids. In the water, a free-living spore stage can then infect other, susceptible fish (Arkush et al., 2003). This versatile life cycle promotes contact with diverse fish species.

Furthermore, as a generalist pathogen, S. destruens can infect multiple hosts, such as the above-mentioned American salmonids (Chinook salmon, Atlantic salmon), but also rainbow trout (Oncorhynchus mykiss) and brown trout (Salmo trutta) (Arkush et al., 1998). More recent studies have also reported infections in cyprinids (sunbleak, Leucaspius delineatus; bream, Abramis brama; carp, Cyprinus carpio; roach, Rutilus rutilus) (Gozlan et al., 2009). Given its potential to infect diverse other species, $S$. destruens has become a major worldwide threat for fish biodiversity (Arkush et al., 2003; Al-Shorbaji et al., 2015). Although many cyprinids are highly susceptible to $S$. destruens infection, the topmouth gudgeon (Pseudorasbora parva) is a healthy carrier of the parasite. This species originates from eastern Asia including Japan, Korea and southeast Siberia (Perdices and Doadrio, 1992), and has successfully colonized European waters since the early 1960s, mainly by accidental introduction. This invasive fish has spread at a high rate, invading five new countries each decade, and is classified as a worldwide pest (Welcomme, 1992; Gozlan et al., 2010). Furthermore, a recent study demonstrated that the topmouth gudgeon has transmitted $S$. destruens to sea bass (Dicentrarchus labrax) farms, leading to significant economic losses (Ercan et al., 2015). Its colonization success can be attributed to its early maturity, high fecundity and ability to adapt to new pathogens and environmental conditions (Gozlan et al., 2010).

In France, this invasive fish species was first reported in 1980 (Allardi and Chancerel, 1988). A survey of fish populations in metropolitan France between 1990 and 2009 showed that this non-native species has spread dramatically (Poulet et al., 2011), colonizing many French rivers.

One of the major issues in the introduction of new species is the transfer of pests to native species. To our knowledge, no study has yet been carried out in France to assess the status of $P$. parva as a carrier of $S$. destruens. This type of investigation is all the more urgent because $P$. parva is also currently suspected of being a new vector of other diseases, such as anguillicolosis in France (Cesco et al., 2001). Here, we used molecular methods to determine whether the French population of topmouth gudgeons can be a vector of $S$. destruens.

Twelve topmouth gudgeons caught by backpack electrofishing in a small stream tributary of the Adour River, near Dax, France, were brought to the laboratory to screen for the presence of $S$. destruens. The internal organs (kidney, liver, $\begin{array}{llll}1 & 2 & 3 & 4\end{array}$

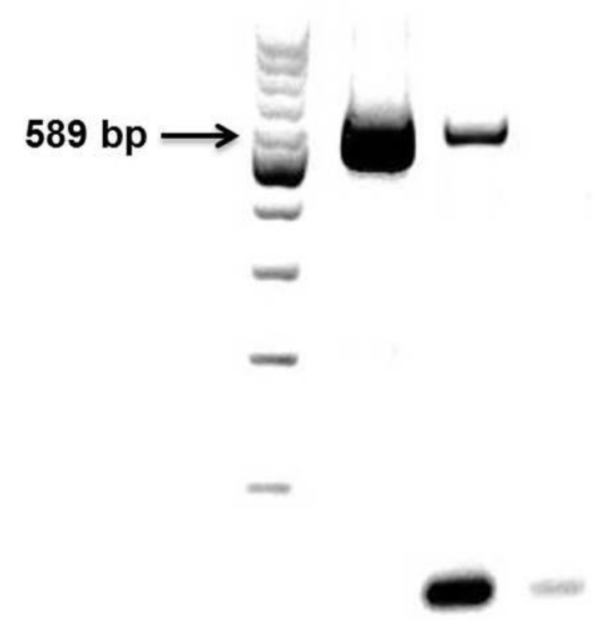

Fig. 1. Molecular detection of the Sphaerothecum destruens 18S gene. Lane 1: 100 bp DNA ladder; Lanes 2 and 3 show PCR products obtained from $300 \mathrm{ng}$ of DNA from the positive control (isolate RA-1) and from $300 \mathrm{ng}$ of DNA from a Pseudorasbora parva sample, respectively; Lane 4: negative control (i.e., no template).

spleen and gonads) from these 12 fish were pooled together. DNA was extracted from $0.1 \mathrm{~g}$ of these pooled organs using the NucleoSpin $^{\oplus}$ Tissue kit (Macherey-Nagel) according to the manufacturer's instructions. Prior to extraction, the samples were crushed in lysis buffer using a tissue homogenizer (Precellys 24 , Bertin), then incubated at $56^{\circ} \mathrm{C}$ overnight with proteinase K. DNA was also extracted from the North American isolate of $S$. destruens (RA-1) deposited in the ATCC under accession number ATCC ${ }^{\oplus} 50643^{\mathrm{TM}}$. This isolate was used as a positive control in the molecular detection experiments. To screen for $S$. destruens DNA, a nested polymerase chain reaction (PCR) protocol targeting the $S$. destruens 18S rRNA gene was performed on $300 \mathrm{ng}$ of sample. PCRs were prepared in $50 \mu \mathrm{L}$ with the HotStar HiFidelity Polymerase Kit (Qiagen) using primer sets F1 (5'-AAT CGT ATG ACA TTT TGT CGA C-3') and R1 (5'-GAA GTC ACA GGC GAT TCG G-3') for the first round, then F2 (5'-ACA GGG CTT TTT AAG TCT TGT- $\left.3^{\prime}\right)$ and R2 (5'-ATG GAG TCA TAG AAT TAA CAT CC- $3^{\prime}$ ) for the second round (Andreou et al., 2011). Thermal cycling conditions used for both PCR rounds were as follows: $94^{\circ} \mathrm{C}$ for $15 \mathrm{~min}, 35$ cycles of $94^{\circ} \mathrm{C}$ for $1 \mathrm{~min}, 55^{\circ} \mathrm{C}$ for $1 \mathrm{~min}$ and $72^{\circ} \mathrm{C}$ for $1 \mathrm{~min}$, followed by a final elongation of $10 \mathrm{~min}$. PCR products were loaded on $2 \%$ agarose gels for electrophoresis. Parasitespecific DNA was amplified from the positive control (RA-1) and from the topmouth gudgeon sample and a band was visible at the expected size $(589 \mathrm{bp})$. The negative control (PCR without template) showed no amplification, ruling out any potential external contamination of the samples (Fig. 1).

The PCR products were sequenced to confirm the presence of $S$. destruens on P. parva sampled in France. First, the PCR product was excised from the gel and purified using Wizard SV Gel and PCR Clean-Up System (Promega) for cloning into pGEM $^{\circledR}$-T Easy Vector (Promega). Three clones were sequenced by GATC Biotech with $\mathrm{T} 7$ and SP6 primers (Nag et al., 1988). The sequences obtained from the gudgeon 


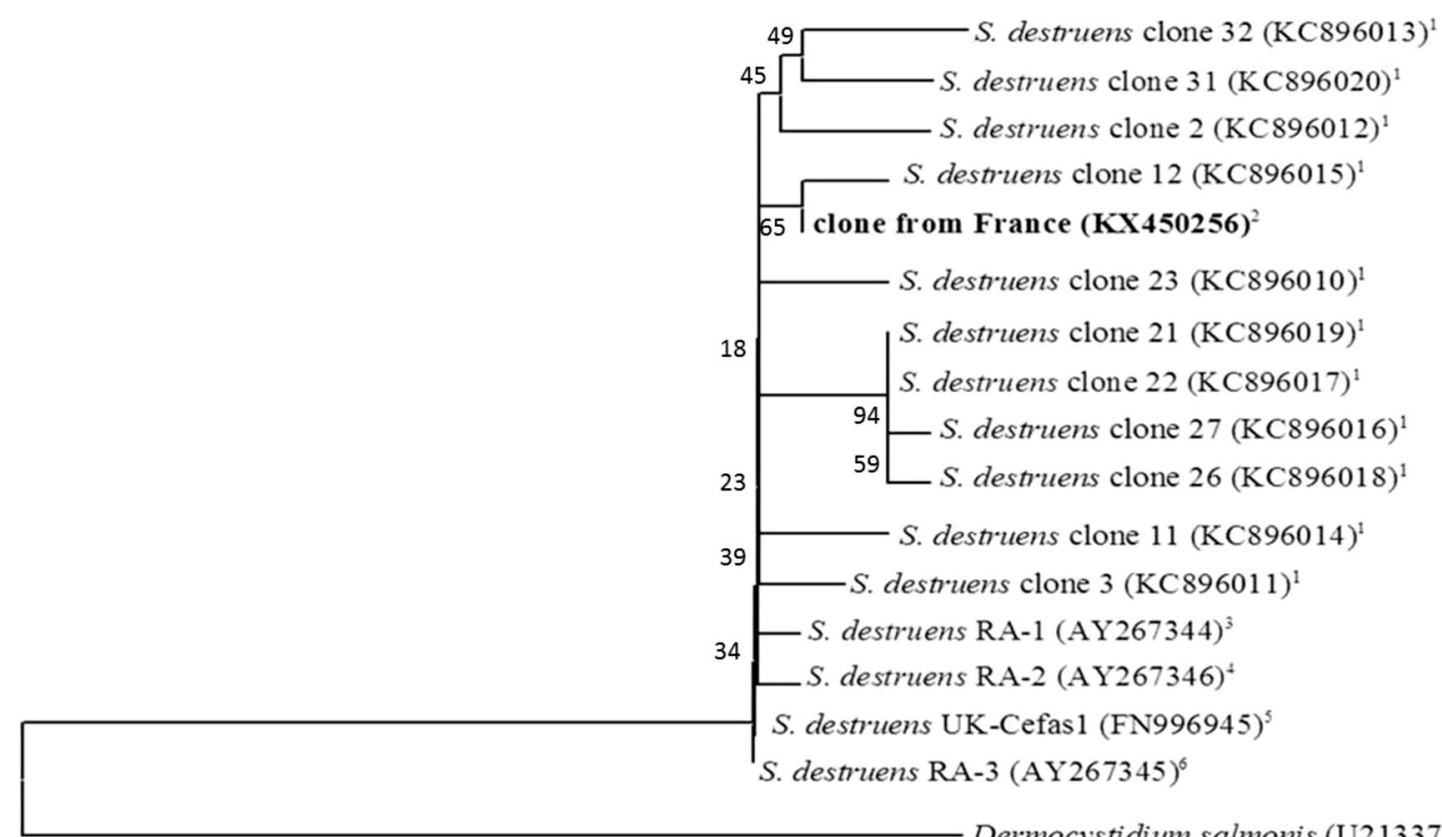

Dermocystidium salmonis (U21337)

0.01

Fig. 2. Phylogenetic tree resulting from the neighbor-joining analysis of the $18 \mathrm{~S}$ rRNA sequences obtained from Pseudorasbora parva sampled in France and Sphaerothecum destruens sequences from GenBank, using MEGA4 software. The Dermocystidium salmonis 18S rRNA sequence was used as an outgroup. The bar represents $1 \%$ sequence divergence. The evolutionary distances were computed using the Maximum Composite Likelihood method and expressed as the number of base substitutions per site. Accession numbers are indicated in parentheses. Fish species associated with $S$. destruens infection, country of discovery and reference are from ${ }^{1}$ topmouth gudgeon in the Netherlands (Spikmans et al., 2013); ${ }^{2}$ topmouth gudgeon in France (this study); ${ }^{3}$ Chinook salmon in Washington, US (Arkush et al., 2003); ${ }^{4}$ Atlantic salmon in US (Arkush et al., 2003); ${ }^{5}$ sunbleak in United Kingdom (Paley et al., 2012); ${ }^{6}$ winter-run Chinook salmon in California, US (Arkush et al., 2003).

DNA sample were checked against ApE (A plasmid Editor by M. Wayne Davis) and a nucleotide BLAST search. This analysis revealed perfect identity between the three sequenced clones and an identity of $99 \%$ between this sequence (deposited in GenBank; accession number KX450256) and known sequences of $S$. destruens in GenBank (E-value 0.0). These sequences were aligned using Clustal X (Thompson et al., 1997) for subsequent phylogenetic analysis based on a neighbor-joining tree constructed using MEGA 4 (Tamura et al., 2007) (Fig. 2). Various 18S rRNA sequences were included in the alignment to represent different infected fish species as well as countries where $S$. destruens infections have been detected. Sequences of North American S. destruens isolates are represented by RA-1, RA-2, and RA-3 (GenBank accession numbers: AY267344; AY267346 and AY267345, respectively). Sequences for European isolates are from $P$. parva found at two different sampling sites in Netherlands (accession numbers KC896010 to KC896020) (Spikmans et al., 2013) and from sunbleak isolated in England (UKCefas1; accession number FN996945). The 18S rRNA sequence from Dermocystidium salmonis isolated from Chinook salmon (accession number U21337) was also used in this analysis as an outgroup. Phylogenetic analysis revealed that the sequence obtained in this study on $P$. parva sampled in France clustered with all $S$. destruens sequences obtained from various infected fish in Europe and North America with very minor differences. Therefore, the sampled topmouth gudgeon population carries the $S$. destruens parasite.
We report here the first evidence of the presence of $S$. destruens in France. Furthermore, this parasite was detected in an invasive fish species, P. parva. Reports from other countries of this host-parasite couple based on molecular methods are rare and only recent: the Netherlands (Spikmans et al., 2013) and Turkey (Ercan et al., 2015). Given that pathogen concentrations in healthy carrier fish are generally very low, diagnostic tests frequently fail to detect the presence of the pathogen (Gozlan et al., 2005). For example, in one study, S. destruens DNA was not detected in P. parva samples, leading to false-negative PCR results (Gozlan et al., 2005).

Invasion by exotic fish species is one of the most important threats to global freshwater biodiversity (Poulet et al., 2011). For example, the decline of the native European fish species L. delineatus has been attributed to the introduction of P. parva and its associated pathogen S. destruens (Gozlan et al., 2005). In addition, other diseases have been associated with P. parva, such as the pike fry rhabdovirus (PFR), which infects juveniles of pike (Esox lucius) (Ahne and Thomsen, 1986) and the swimbladder nematode Anguillicola crassus, which infects the European eel Anguilla anguilla (Cesco et al., 2001). The European eel is already classified as a critically endangered species in France (Poulet et al., 2011). The ecological and economic costs of invasive introduced species are high, and these species expose fish farms to high risks of infection. A more extensive investigation of the prevalence of $S$. destruens in $P$. parva populations needs to be carried out at defined sites in France, in particular in fisheries where $P$. parva has been 
reported (Andreou and Gozlan, 2016). This type of study should be set up using a specific sampling strategy, with molecular screening on a minimum of 30 fish per population. In areas where $S$. destruens is detected, wild populations in adjacent water bodies should also be screened for $S$. destruens. Phylogenetic studies based on ribosomal internal spacer region (ITS) sequences would be useful to investigate geographical differences between isolates.

In conclusion, the preliminary data reported here highlight the urgent need to establish aquatic ecosystem management programs in France to preserve fish diversity.

Acknowledgements. We are grateful to Rodolphe E. Gozlan (IRD, France) and Didem Ercan (Faculty of Fisheries, Turkey) for their helpful advice. We also wish to thank Delphine Gey (MNHN, France) for helpful discussions, Karine Ricaud (IUT des Pays de l'Adour, Département Génie Biologique, France), Carolyn Engel-Gautier and our colleague Isabelle Vitte (LPL, France) for their comments on this manuscript.

\section{References}

Ahne W, Thomsen I. 1986. Isolation of pike fry rhabdovirus from Pseudorasbora parva (Temminck and Schlegel). J Fish Dis 9: $555-556$.

Al-Shorbaji FN, Gozlan RE, Roche B, Britton JR, Andreou D. 2015. The alternate role of direct and environmental transmission in fungal infectious disease in wildlife: threats for biodiversity conservation. Sci Rep 5: 10368.

Allardi J, Chancerel F. 1988. Note ichtyologique. Sur la présence en France de Pseudorasbora parva (Schlegel, 1842). Bull Fr Pêche Piscic 308: 35-37.

Andreou D, Gozlan RE. 2016. Associated disease risk from introduced generalist pathogen Sphaerothecum destruens: management and policy implications. Parasitology 143: 1204-1210.

Andreou D, Gozlan RE, Stone D, Martin P, Bateman K, Feist SW. 2011. Sphaerothecum destruens pathology in cyprinids. Dis Aquat Org 95: 145-151.

Arkush KD, Frasca S, Hedrick RP. 1998. Pathology associated with the rosette agent, a systemic protist infecting salmonid fishes. $J$ Aquat Anim Health 10: 1-11.

Arkush KD, Mendoza L, Adkison MA, Hedrick RP. 2003. Observations on the life stages of Sphaerothecum destruens n.g., n.sp., a Mesomycetozoean fish pathogen formerly referred to as the rosette agent. $J$ Eukaryot Microbiol 50: 430-438.

Cesco H, Lambert A, Crivelli AJ. 2001. Pseudorasbora parva (Téléostéen, Cyprinidae) espèce invasive, nouvel agent du maintien et de la dissémination de l'anguillicolose en France? Parasite 8: 75-76.

Ercan D, Andreou D, Sana S, et al. 2015. Evidence of threat to European economy and biodiversity following the introduction of an alien pathogen on the fungal-animal boundary. Emerg Microbes Infect 4: e52.

Gozlan RE, St-Hilaire S, Feist SW, Martin P, Kent ML. 2005. Biodiversity: disease threat to European fish. Nature 435: 1046.

Gozlan RE, Whipps CM, Andreou D, Arkush KD. 2009. Identification of a rosette-like agent as Sphaerothecum destruens, a multihost fish pathogen. Int J Parasitol 39: 1055-1058.

Gozlan RE, Andreou D, Asaeda T, et al., 2010. Pan-continental invasion of Pseudorasbora parva: towards a better understanding of freshwater fish invasions. Fish Fish 11: 315-340.

Harrell LW, Elston RA, Scott TM, Wilkinson MT. 1986. A significant new systemic disease of net-pen reared chinook salmon (Oncorhynchus tshawytscha) brood stock. Aquaculture 55: 249262.

Hedrick RP, Friedman CS, Modin J. 1989. Systemic infection in Atlantic salmon Salmo salar with a Dermocystidium-like species. Dis Aquat Org 7: 171-177.

Nag DK, Huang HV, Berg DE. 1988. Bidirectional chain-termination nucleotide sequencing: transposon Tn5seq1 as a mobile source of primer sites. Gene 64: 135-145.

Paley RK, Andreou D, Bateman KS, Feist SW. 2012. Isolation and culture of Sphaerothecum destruens from Sunbleak (Leucaspius delineatus) in the UK and pathogenicity experiments in Atlantic salmon (Salmo salar). Parasitology 139: 904-914.

Perdices A, Doadrio I. 1992. Presence of the asiatic cyprinid Pseudorasbora parva (Schlegel, 1842) in North Africa. Misc Zool 16: 236-239.

Poulet N, Beaulaton L, Dembski S. 2011. Time trends in fish populations in metropolitan France: insights from national monitoring data. J Fish Biol 79: 1436-1452.

Spikmans F, van Tongeren T, van Alen TA, van der Velde G, Op den Camp HJM. 2013. High prevalence of the parasite Sphaerothecum destruens in the invasive topmouth gudgeon Pseudorasbora parva in the Netherlands, a potential threat to native freshwater fish. Aquat Invasions 8: 355-360.

Tamura K, Dudley J, Nei M, Kumar S. 2007. MEGA4: Molecular Evolutionary Genetics Analysis (MEGA) software version 4.0. Mol Biol Evol 8: 1596-1599.

Thompson JD, Gibson TJ, Plewniak F, Jeanmougin F, Higgins DG. 1997. The CLUSTAL_X windows interface: flexible strategies for multiple sequence alignment aided by quality analysis tools. Nucleic Acids Res 24: 4876-4882.

Welcomme RL. 1992. A history of international introductions of inland aquatic species. ICES Mar Sci Symp 194: 3-14.

Cite this article as: Charrier A, Peudpiece M, Lesne M, Daniel P. 2016. First report of the intracellular fish parasite Sphaerothecum destruens associated with the invasive topmouth gudgeon (Pseudorasbora parva) in France. Knowl. Manag. Aquat. Ecosyst., $417,44$. 